\title{
KEADILAN DALAM RETRIBUSI PARKIR BERLANGGANAN
}

\author{
Ahmad Munir ${ }^{1}$, Moh. Hudi ${ }^{2}$ \\ Universitas Islam Darul 'Ulum \\ 1ahmadmunir@unisda.ac.id, ${ }^{2}$ mohhudi@unisda.ac.id
}

\begin{abstract}
The regional government has the authority to regulate and manage government affairs on the basis of regional autonomy. The presence of parking fees is one of the results of the regional autonomy regulation. Subscription parking levies are applied by various regions, but there is a contradiction with Law Number 28 of 2009 concerning Regional Taxes and Regional Levies and can harm the public. For this reason, it is necessary to study justice in the application of subscription parking fees.

The methodology used is the legislative approach and the conceptual approach by examining legislation and doctrines relating to subscription parking fees. The purpose of this study is to examine and find appropriate regulations in the application of parking fees. The application of parking fees for subscription parking fees cannot be forced or required for all people because it is not in accordance with the concept of retribution and and the basis of justice. For this reason, the application of subscription parking cannot be forced on all parking retribution subjects to bring about of justice.
\end{abstract}

Keywords: justice, retribution, parking.

\begin{abstract}
ABSTRAK
Pemerintah daerah berwenang mengatur serta mengurus sendiri urusan pemerintahan dengan dasar otonomi daerah. Adanya retribusi parkir merupakan salah satu hasil dari regulasi otonomi daerah. Retribusi parkir berlangganan diterapkan oleh berbagai daerah, akan tetapi timbul suatu pertentangan dengan Undang-Undang Nomor 28 Tahun 2009 tentang Pajak daerah dan Retribusi Daerah serta dapat merugikan masyarakat. Untuk itu perlu adanya kajian keadilan dalam penerapan retribusi parkir berlangganan.

Metodologi dalam penelitian ini adalah menggunakan pendekatan perundangundangan serta pendekatan konseptual dengan menelaah peraturan perundangundangan dan doktrin yang berkaitan dengan retribusi parkir berlangganan. Tujuan dari penelitian ini adalah mengkaji dan menemukan regulasi yang sesuai dalam penerapan retribusi parkir. Penerapan retribusi parkir retribusi parkir berlangganan tidak dapat dipaksakan atau diwajibkan bagi semua masyarakat karena tidak sesuai dengan konsep retribusi dan dan dasar keadilan. Untuk itu adanya penerapan parkir berlangganan tidak dapat dipaksakan terhadap semua subjek retribusi parkir agar timbul adanya keadilan.
\end{abstract}

Kata Kunci : keadilan, retribusi, parkir. 


\section{PENDAHULUAN}

Negara Indonesia merupakan negara kesatuan yang berbentuk Republik sesuai dengan Pasal 1 ayat (1) Undang-Undang Dasar Negara Republik Indonesia Tahun 1945 yang selanjutnya disingkat UUD NRI 1945. Kekuasaan negara tidak hanya dilaksanakan oleh pemerintah pusat, tetapi juga oleh pemerintahan daerah yang diatur dalam Bab VI, pasal 18, 18A, dan 18B UUD NRI Tahun 1945. Maksud dari pemerintah daerah adalah pemerintahan daerah provinsi, kabupaten, dan kota yang berwenang untuk mengatur serta mengurus sendiri urusan pemerintahan dengan dasar asas otonom dan tugas pembantuan (Pasal 18 ayat (2) UUD NRI Tahun 1945).

Sistem pemerintahan negara telah berubah pasca reformasi, dari yang terpusat di atas atau sentralisasi menjadi desentralisasi atau otonomi daerah. Pengakuan Negara terhadap kemandirian, pemberdayaan masyarakat, dan mendekatkan pelayanan yang dilakukan oleh pemerintah kepada masyarakat merupakan bentuk penyelenggaraan otonomi daerah. ${ }^{1}$ Hal tersebut tentu memberikan kewenangan terhadap daerah untuk mengatur daerahnya sesuai dengan kebutuhannya. Tujuan adanya otonomi daerah adalah agar daerah dapat melakukan kreasi dalam menggali potensi pendapatan daerah yang dapat digunakan untuk pembiayaan daerah. ${ }^{2}$ Hak dan kewenangan daerah untuk mengurus dan mengatur daerahnya sendiri adalah dasar dari otonomi daerah. Hak tersebut didapatkan melalui penyerahan urusan pemerintah pusat kepada pemerintah daerah sesuai dengan kemampuan dan keadaan daerah yang bersangkutan. Asas desentralisasi merupakan wujud dari otonomi daerah yang harapannya dapat mengoptimalkan pelayanan terhadap masyarakat. ${ }^{3}$

Daerah memiliki Anggaran Pendapatan Belanja Daerah (selanjutnya disingkat APBD) dan Pendapatan Asli Daerah (selanjutnya disingkat PAD). Khusus PAD, setiap daerah diberikan kewenangan untuk meningkatkan pendapatan asli daerah. Perihal tersebut dilaksanakan supaya daerah dapat lebih mengembangkan dan memajukan daerahnya. Di samping itu daerah juga lebih memahami rumah tangganya sendiri sehingga daerah secara otomatis mengetahui apa yang harus dijalankan dan apa yang

\footnotetext{
${ }^{1}$ Fatkhul Muin, "Otonomi Daerah Dalam Perspektif Pembagian Urusan Pemerintah-Pemerintah Daerah Dan Keuangan Daerah”, Fiat Justisia, Vol. 8 No. 1 Januari-Maret 2014, h. 72.

${ }^{2}$ Ahmad Munir dan Dea Arifka Andini, "Pengaturan Pajak Restoran Atas Food Truck Menurut Undang-Undang Nomor 28 Tahun 2009 Tentang Pajak Daerah Dan Retribusi Daerah", Mimbar Yustitia, UNISDA Press, Vol. 1 No. 1, 2017, h. 93.

${ }^{3}$ Sakinah Nadir, “Otonomi Daerah Dan Desentralisasi Desa: Menuju Pemberdayaan Masyarakat Desa”, Politik Profetik, Vol. 1 No. 1, 2013, h. 2.
} 
dibutuhkan untuk meningkatkan kualitas daerahnya. UUD NRI 1945 Pasal 18 ayat (1) menyatakan bahwa Negara Indonesia terbagi atas daerah provinsi yang selanjutnya dibagi atas kota dan kabupaten, memiliki pemerintahan daerah dengan diatur oleh Undang-Undang.

Kebijakan pemungutan retribusi parkir berlangganan di Kabupaten Lamongan merupakan upaya pemerintah daerah dalam mengembangkan dan menggali sumbersumber potensi daerah dalam tujuan meningkatkan pendapatan daerah untuk mencapai tujuan pemerintah daerah yang dicapai, termasuk kelancaran lalu lintas, mengelola tata ruang kota, dan pelayanan publik, serta yang paling penting adalah untuk memenuhi kebutuhan dan mensejahterahkan masyarakat. Pelayanan atas retribusi parkir berlangganan yang sudah dibayarkan merupakan suatu hal yang harus diwujudkan oleh pemerintah dalam memenuhi kebutuhan masyarakat. Pelayanan publik tersebut harus berkualitas, dan harus dilakukan terus menerus serta mempertahankan kualitas yang diberikan. Berkualitas artinya mengoptimalkan pelayanan terhadap masyarakat sesuai dengan kebutuhannya dalam penerapan retribusi parkir berlangganan yang ada di Kabupaten Lamongan.

Penerapan retribusi parkir berlangganan yang merupakan salah satu sumber pendapatan daerah Kabupaten Lamongan, ternyata tidak tanpa masalah. Mulai dari aspek pelaksanaannya dilapangan yakni adanya oknum yang tidak beranggungjawab dalam menggunakan tempat tertentu dalam mangambil keuntungan dan pengelolaan hasil retribusi parkir yang belum transparan. Hal yang paling tidak logis, lokasi samsat sebagai tempat pembayaran retribusi parkir berlangganan tetap memungut retribusi parkir kepada warga masyarakat yang melakukan registrasi atau perpanjangan surat tanda nomor kendaraan. Peraturan Daerah Kabupaten Lamongan Nomor 15 Tahun 2010 tentang Retribusi Pelayanan Parkir di Tepi Jalan umum ${ }^{4}$ banyak diperdebatkan oleh kalangan masyarakat Lamongan, bahkan dengan adanya isu revisi atas Peraturan Daerah ini oleh Kementerian Dalam Negeri yang dianggap merugikan masyarakat dan bertentangan dengan Undang-Undang Nomor 28 Tahun 2009 tentang Pajak daerah dan Retribusi Daerah. ${ }^{5}$ Untuk itu perlu dan penting adanya kajian aspek keadilan dalam penerapan retribusi parkir berlangganan.

\footnotetext{
${ }^{4}$ Selanjutnya disingkat Perda Lamongan No. 15 Tahun 2010

${ }^{5}$ Lembaran Negara Republik Indonesia Tahun 2009 Nomor 130, Tambahan Lembaran Negara Republik Indonesia Nomor 504, yang selanjutnya disingkat UU PDRD
} 


\section{METODOLOGI}

Pendekatan yang digunakan adalah: (1) Statute Approach, dimana peneliti akan menelaah regulasi perundang-undangan yang berlaku berkaitan dengan retribusi parkir berlangganan, selanjutnya (2) Conceptual Approach, yaitu pendekatan dengan cara membahas doktrin keadilan yang menjadi pioner dalam ilmu hukum sehingga dapat ditemukan ide-ide sesuai dengan topik permasalahan. Tujuan penelitian ini adalah mengkaji dan menemukan regulasi yang sesuai dalam penerapan retribusi parkir.

\section{PEMBAHASAN}

Sumber penerimaan negara yang memenuhi kriteria sebagai pungutan tersebut menurut C.Goedhart adalah pajak, retribusi, sumbangan, dan denda. ${ }^{6}$ Jenis pungutan yang dilakukan oleh pemerintah di Indonesia menurut Diana Sari selain pajak negara seperti pajak penghasilan, pajak pertambahan nilai, pajak penjualan atas barang mewah, bea meterai, dan bea cukai. Pemerintah Daerah memungut pajak daerah, retribusi serta penerimaan lainnya yang dapat dikategorikan sebagai Penerimaan Negara Bukan Pajak. ${ }^{7}$

Setidaknya terdapat tiga jenis pungutan yang secara umum berlangsung di masyarakat menurut Marihot Pahala Siahaan yaitu pajak, retribusi, dan sumbangan. ${ }^{8}$ Pengertian masing-masing pungutan tersebut adalah sebagai berikut:

\section{Pajak}

Konsep pajak berdasarkan Undang-undang Nomor 28 Tahun 2007 tentang Ketentuan Umum Perpajakan ${ }^{9}$ pasal 1 ayat (1) bahwa Pajak merupakan kontribusi atau peran serta wajib kepada negara oleh orang pribadi atau badan berdasarkan undangundang dengan tidak mendapatkan kontraprestasi langsung untuk keperluan negara dgan tujuan kemakmuran rakyat. Definisi pajak juga terdapat dalam Undang-Undang

${ }^{6}$ C.Goedhart, Garis-garis Besar Ilmu Keuangan Negara, Jakarta, Penerbit Djambatan, 1975, h. 120 .

${ }^{7}$ Diana Sari, Konsep Dasar Perpajakan, Refika Aditama, Bandung, 2013, h.42.

${ }^{8}$ Marihot Pahala Siahaan, Hukum Pajak Elementer Konsep Dasar Perpajakan Indonesia, Seri Hukum Pajak Indonesia, Cetakan Pertama, Graha Ilmu, Yogyakarta, 2010, h.25.

${ }^{9}$ Lembaran Negara Republik Indonesia Tahun 1983 Nomor 49, Tambahan Lembaran Negara Republik Indonesia Nomor 3262, sebagaimana diubah dengan Undang-Undang Nomor 16 Tahun 2000 tentang Perubahan Kedua atas Undang-Undang Nomor 6 Tahun 1983 (Lembaran Negara Republik Indonesia Tahun 2000 Nomor 126, Tambahan Lembaran Negara Republik Indonesia Nomor 3984), sebagaimana diubah dengan Undang-Undang Nomor 28 Tahun 2007 tentang Perubahan Ketiga atas Undang-Undang Nomor 6 Tahun 1983 (Lembaran Negara Republik Indonesia Tahun 2007 Nomor 85, Tambahan Lembaran Negara Republik Indonesia Nomor 4740), untuk selanjutnya disingkat UU KUP. 
Nomor 14 Tahun 2002 tentang Pengadilan Pajak ${ }^{10}$ pasal 1 ayat (2) menyatakan bahwa Pajak dalam arti luas yakni pungutan segala jenis pajak oleh pemerintah pusat baik Cukai serta Bea Masuk, dan pungutan pajak oleh Pemerintah Daerah yang didasarkan perundang-undangan yang berlaku. Banyak ragam istilah yang digunakan untuk menjelaskan sifat pajak tersebut ditanggapi oleh Thomas M.Cooley sebagai berikut:"While this definition of taxes characterizes them as 'contributor' other definition refer to them as 'impost', 'duty or impost', 'charges', 'burdens', or 'exactions', but these variations in phraseology are of no practical importance". 11 Bertambahnya penghasilan negara atau daerah yang berasal dari masyarakat, sebaliknya berkurangnya kekayaan atau penghasilan masyarakat yang pada akhirnya akan dikembalikan lagi kepada masyarakat dengan melalui pengeluaran-pengeluaran negara atau daerah. ${ }^{12}$

\section{Retribusi}

Pengertian retribusi yang terdapat dalam literatur menurut Marihot Pahala Siahaan menyatakan bahwa retribusi merupakan pembayaran yang bersifat memaksa dari negara karena jasa yang diberikan oleh negara kepada warganegara secara perorangan yang membayar retribusi atas jasa dari negara. ${ }^{13}$ Definisi retribusi juga diberikan B.Boediono yakni pembayaran yang dilakukan oleh mereka yang menikmati jasa negara secara langsung. ${ }^{14}$ Selanjutnya pengertian retribusi menurut Muhammad Djafar Saidi bahwa pungutan yang bersifat memaksa dengan tegenprestasi secara langsung serta dapat dipaksakan penagihannya oleh pejabat retribusi kepada wajib retribusi dengan pengenaan sanksi administrasi maupun sanksi pidana untuk memaksakan penagihan. ${ }^{15}$

${ }^{10}$ Lembaran Negara Republik Indonesia Tahun 2002 Nomor 27, Tambahan Lembaran Negara Republik Indonesia Nomor 4189.

${ }^{11}$ Bryan A. Garner, Editor, Black's Law Dictionary, Tenth Edition, West Publishing Co, United State Of America, 2014, h.1685.

${ }^{12}$ Ahmad Munir, "Pembebasan Pajak pertambahan nilai atas Usaha Mikro Kecil dan Menengah", Humanis, UNISDA Press, Vol. 3 No. 1, 2011, h. 68.

${ }^{13}$ Marihot Pahala Siahaan, Pajak Daerah dan Retribusi Daerah Berdasarkan Undang-Undang Nomor 28 Tahun 2009 tentang Pajak Daerah dan Retribusi Daerah, RajaGrafindo Persada, Jakarta, 2010 , h.37.

14 B.Boediono, Perpajakan Indonesia, Teori Perpajakan Kebijaksanaan Pajak Luar Negeri, Diadit Media, Jakarta, 2000, h.14.

${ }^{15}$ Muhammad Djafar Saidi, Pembaruan Hukum Pajak, Cetakan Ke-4, RajaGrafindo Persada, Jakarta, 2014, h.31. 
Pungutan retribusi yang dilakukan oleh pemerintah daerah disebut retribusi daerah. Definisi retribusi daerah terdapat dalam pasal 1 angka (64) UU PDRD yakni pungutan yang dilakukan oleh daerah kepada orang pribadi atau badan sebagai pembayaran atas pemberian izin atau jasa tertentu yang khusus diberikan dan/atau disediakan.

Jenis retribusi jasa umum salah satunya adalah retribusi pelayanan parkir di tepi jalan umum yang dijabarkan dalam Pasal 110 ayat (1) UU PDRD bahwa pelayanan yang diberikan atau disediakan Pemerintah Daerah yang dapat dimanfaatkan baik oleh orang pribadi maupun badan dengan tujuan kepentingan dan kemanfaatan bersama. Pasal 125 ayat (1) UU PDRD bahwa orang maupun badan hukum yang memanfaatkan pelayanan jasa umum yang bersangkutan merupakan subjek retribusi jasa umum. Sedangkan wajib retribusi jasa umum dijabarkan pasal 125 ayat (2) UU PDRD bahwa orang atau badan hukum diwajibkan untuk melakukan pembayaran retribusi, termasuk pemotong maupun pemungut retribusi jasa umum menurut ketentuan peraturan perundang-undangan.

Konsep retribusi parkir berlangganan didasarkan pada konsep bahwa retribusi wajib bagi orang yang menerima pelayanan. Obyek Retribusi pelayanan parkir di tepi jalan umum pelaksanaannya diatur dalam Perda Lamongan No. 15 Tahun 2010 pasal 3 bahwa penyediaan pelayanan parkir di tepi jalan umum dapat dilakukan dengan parkir harian dan parkir berlangganan yang ditentukan oleh Pemerintah Daerah sesuai dengan regulasi perundang-undangan yang berlaku. Retribusi parkir harian diwajibkan apabila subjek retribusi menerima pelayanan secara langsung dari petugas parkir. Berbeda dengan retribusi parkir berlangganan yang diwajibkan untuk membayar secara langsung dengan tidak mendapatkan pelayanan secara langsung. Untuk itu sesuai dengan konsep retribusi dalam UU PDRD bahwa Retribusi parkir wajib bagi yang menerima pelayanan secara langsung, sehingga parkir berlangganan tidak sesuai dengan konsep tersebut.

Mengkaji peraturan retribusi parkir berlangganan tidak cukup dengan hanya tinjauan konseptual akan tetapi titik beratnya dalam aspek keadilan. Teori keadilan menurut McCoubrey dan White, yang dimaksud dengan keadilan adalah a condition in which the optimum balance is achieved between individual aspiration and collective need (which may be seen as a sum total of the combined individual aspirations of the 
member of a society). ${ }^{16}$ Sementara ketidakadilan adalah a condition of society in which the humanity of the people living in it, both as individuals and as social creatures, is fundamentally denied. ${ }^{17}$ Sesuai teori tersebut maka penerapan retribusi parkir seyogianya menghindari timbulnya kondisi ketidakadilan, khususnya dalam penerapan parkir berlangganan. Subjek retribusi parkir tidak semuanya memanfaatkan pelayanan parkir di tepi umum, maka tidak semua subjek retribusi parkir menjadi wajib retribusi parkir. Untuk itu adanya penerapan parkir berlangganan tidak dapat dipaksakan terhadap semua subjek rertribusi parkir agar timbul adanya keadilan.

\section{KESIMPULAN}

Otonomi daerah memberikan kewenangan terhadap daerah untuk mengatur daerahnya sesuai dengan kebutuhannya. Adanya retribusi parkir yang dipungut oleh daerah merupakan salah satu regulasi adanya otonomi daerah. Konsep retribusi dilakukan apabila menerima pelayanan secara langsung. Penerapan retribusi parkir berlangganan yang diwajibkan untuk membayar secara langsung dengan tidak mendapatkan pelayanan secara langsung. Maka konsep penerapan retribusi parkir berlangganan tidak sesuai dengan konsep retribusi. Selain itu penerapan retribusi parkir harus dilakukan dengan dasar keadilan. Subjek retribusi parkir berlangganan tidak semuanya memanfaatkan pelayanan parkir di tepi umum, maka adanya retribusi parkir berlangganan tidak dapat dipaksakan atau diwajibkan bagi semua masyarakat. Untuk itu adanya penerapan parkir berlangganan tidak dapat dipaksakan terhadap semua subjek retribusi parkir agar timbul adanya keadilan.

Perlindungan hukum terhadap wajib retribusi parkir harus diberikan, untuk itu perlu adanya revisi berkaitan dengan aturan retribusi parkir berlangganan yang bersifat wajib menjadi sebuah pilihan bagi wajib retribusi. Pemerintah daerah juga harus mengoptimalkan pendapatan dan pelayanan terhadap wajib retribusi parkir dengan upaya memberikan karcis berhadiah langsung apabila beruntung.

\footnotetext{
${ }^{16}$ Hilaire McCoubrey dan Nigel D. White, Textbook on Jurisprudence, Blackstone Press Ltd., London, 1996, h. 286.

${ }^{17}$ Ibid., h. 287.
} 


\section{DAFTAR BACAAN}

\section{Buku dan Jurnal}

Boediono, B., Perpajakan Indonesia, Teori Perpajakan Kebijaksanaan Pajak Luar Negeri, Diadit Media, Jakarta, 2000.

Diana Sari, Konsep Dasar Perpajakan, Refika Aditama, Bandung, 2013.

Garner, Bryan A., Editor, Black's Law Dictionary, Tenth Edition, West Publishing Co, United State Of America, 2014.

Goedhart, C., Garis-garis Besar Ilmu Keuangan Negara, Jakarta, Penerbit Djambatan, 1975 ,

McCoubrey, Hilaire, dan Nigel D. White, Textbook on Jurisprudence, Blackstone Press Ltd., London, 1996.

Muin, Fatkhul, "Otonomi Daerah Dalam Perspektif Pembagian Urusan PemerintahPemerintah Daerah Dan Keuangan Daerah", Fiat Justisia, Vol. 8 No. 1 JanuariMaret 2014.

Munir, Ahmad, "Pembebasan Pajak pertambahan nilai atas Usaha Mikro Kecil dan Menengah", Humanis, UNISDA Press, Vol. 3 No. 1, 2011.

Munir, Ahmad, dan Dea Arifka Andini, "Pengaturan Pajak Restoran Atas Food Truck Menurut Undang-Undang Nomor 28 Tahun 2009 Tentang Pajak Daerah Dan Retribusi Daerah", Mimbar Yustitia, UNISDA Press, Vol. 1 No. 1, 2017.

Nadir, Sakinah, "Otonomi Daerah Dan Desentralisasi Desa: Menuju Pemberdayaan Masyarakat Desa”, Politik Profetik, Vol. 1 No. 1, 2013.

Saidi, Muhammad Djafar, Pembaruan Hukum Pajak, Cetakan Ke-4, RajaGrafindo Persada, Jakarta, 2014.

Siahaan, Marihot Pahala, Hukum Pajak Elementer Konsep Dasar Perpajakan Indonesia, Seri Hukum Pajak Indonesia, Cetakan Pertama, Graha Ilmu, Yogyakarta, 2010.

\section{Pajak Daerah dan Retribusi Daerah Berdasarkan} Undang-Undang Nomor 28 Tahun 2009 tentang Pajak Daerah dan Retribusi Daerah, RajaGrafindo Persada, Jakarta, 2010.

\section{Peraturan Perundang-undangan}

Undang Undang Dasar Negara Republik Indonesia Tahun 1945.

Undang-undang Nomor 6 Tahun 1983 tentang Ketentuan Umum Perpajakan (Lembaran Negara Republik Indonesia Tahun 1983 Nomor 49, Tambahan Lembaran Negara Republik Indonesia Nomor 3262).

Undang-Undang Nomor 16 Tahun 2000 tentang Perubahan Kedua atas UndangUndang Nomor 6 Tahun 1983 (Lembaran Negara Republik Indonesia Tahun 
2000 Nomor 126, Tambahan Lembaran Negara Republik Indonesia Nomor 3984).

Undang-Undang Nomor 28 Tahun 2007 tentang Perubahan Ketiga atas UndangUndang Nomor 6 Tahun 1983 (Lembaran Negara Republik Indonesia Tahun 2007 Nomor 85, Tambahan Lembaran Negara Republik Indonesia Nomor 4740).

Undang-Undang Nomor 14 Tahun 2002 tentang Pengadilan Pajak (Lembaran Negara Republik Indonesia Tahun 2002 Nomor 27, Tambahan Lembaran Negara Republik Indonesia Nomor 4189).

Undang-Undang Nomor 28 Tahun 2009 tentang Pajak daerah dan Retribusi Daerah (Lembaran Negara Republik Indonesia Tahun 2009 Nomor 130, Tambahan Lembaran Negara Republik Indonesia Nomor 504).

Peraturan Daerah Kabupaten Lamongan Nomor 15 Tahun 2010 tentang Retribusi Pelayanan Parkir di Tepi Jalan umum. 